\title{
Efektivitas worked example dengan strategi pengelompokan siswa ditinjau dari kemampuan pemecahan masalah dan cognitive load
}

\author{
Muhammad Ferry Irwansyah ${ }^{1 *}$, Endah Retnowati ${ }^{2}$ \\ ${ }^{1}$ SMP Muhammadiyah 1 Depok, Stan, Maguwoharjo, Depok, Sleman 55282 \\ ${ }^{2}$ Program Studi Pendidikan Matematika, Program Pascasarjana, Universitas Negeri Yogyakarta. \\ Jalan Colombo No. 1, Karangmalang, Yogyakarta 55281, Indonesia. \\ E-mail: ferryirwansyah90@gmail.com \\ * Corresponding Author
}

\begin{tabular}{|c|c|}
\hline ARTICLE INFO & ABSTRACT \\
\hline $\begin{array}{l}\text { Article history } \\
\text { Received: } 3 \text { Oct. 2018; } \\
\text { Revised: } 7 \text { March 2019; } \\
\text { Accepted: } 6 \text { June } 2019\end{array}$ & $\begin{array}{l}\text { Pada penelitian ini bertujuan untuk mendeskripsikan dan membandingkan } \\
\text { efektivitas strategi pembelajaran worked example dan problem solving dengan } \\
\text { strategi pengelompokan siswa (kolaboratif dan individual) ditinjau dari } \\
\text { kemampuan pemecahan masalah dan cognitive load. Penelitian ini melibatkan } \\
64 \text { siswa kelas } 8 \text { sebagai partisipan penelitian yang dibagi menjadi empat }\end{array}$ \\
\hline $\begin{array}{l}\text { Keywords } \\
\text { kolaboratif; kemampuan } \\
\text { pemecahan masalah; } \\
\text { collaborative; worked } \\
\text { example; problem solving } \\
\text { abilities; cognitive load }\end{array}$ & $\begin{array}{l}\text { kelompok secara acak dengan menggunakan desain eksperimen } 2 \times 2 \text { (worked } \\
\text { example vs. problem solving) } \times \text { kolaboratif vs. individual). Hasil penelitian ini } \\
\text { mengindikasikan bahwa tidak terdapat perbedaan signifikan penerapan strategi } \\
\text { worked example dengan pengelompokan kolaboratif dan individual ditinjau } \\
\text { dari kemampuan pemecahan masalah. Ditinjau dari cognitive load, strategi } \\
\text { worked example efektif ketika siswa belajar individual, namun tidak efektif } \\
\text { ketika siswa belajar secara kolaboratif. Ketika siswa belajar secara individual, } \\
\text { strategi worked example dapat mengaktifkan cognitive load lebih rendah } \\
\text { daripada strategi problem solving, sedangkan ketika siswa belajar secara } \\
\text { kolaboratif, strategi worked example dan problem solving tidak berbeda dalam } \\
\text { mereduksi cognitive load. }\end{array}$ \\
\hline
\end{tabular}

The study aimed to describe and compare the effectiveness of learning strategies (worked example and problem-solving) with the strategy of grouping students (collaborative and individual) viewed from problem-solving abilities and cognitive load. There were 64 of 8th-grade students as study participants divided into four groups randomly using experimental design $2 \times 2$ (worked example vs. problem-solving $\times$ collaborative vs. individual). The results of the study indicate that there is no significant difference implementation of worked example strategy between the collaborative strategies and individuals viewed from problem-solving abilities. Viewed from the cognitive load, the worked example strategy was effective when students learn individually, but it was not effective when students learn collaboratively. When students learn individually, worked example strategies could activate cognitive load lower than problemsolving strategies, whereas when students learn collaboratively, worked example strategies and problem-solving were no different in reducing cognitive load.

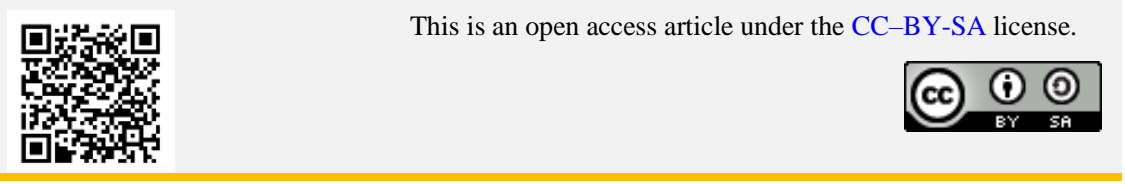

How to Cite: Irwansyah, M., \& Retnowati, E. (2019). Efektivitas worked example dengan strategi pengelompokan siswa ditinjau dari kemampuan pemecahan masalah dan cognitive load. Jurnal Riset Pendidikan Matematika, 6(1), 62-74. doi:https://doi.org/10.21831/jrpm.v6i1.21452 


\section{PENDAHULUAN}

Pembelajaran matematika tidak terlepas dari kegiatan siswa dalam memecahkan permasalahan. Pembelajaran berbasis pemecahan masalah wajib diajarkan dalam pembelajaran matematika dikarenakan pemecahan masalah merupakan inti dari pembelajaran matematika (Stepanek, 2000). Senada dengan itu, NCTM (2000) menyatakan fokus dalam pembelajaran matematika adalah penyelesaian masalah. Pernyataan itu juga didukung oleh Retnowati, Ayres, dan Sweller (2010) bahwa aktivitas utama dalam belajar matematika adalah penyelesaian masalah. Pemecahan permasalahan tidak selalu efektif untuk semua siswa (Chen, Kalyuga, \& Sweller, 2015). Bagi siswa yang telah mendapatkan pengetahuan untuk menyelesaikan permasalahan tersebut maka siswa cenderung lebih mudah dalam menyelesaikan masalahnya. Berbeda halnya dengan siswa yang memiliki keterbatasan pengetahuan awalnya (limited prior knowledge) dan mendapatkan permasalahan yang baru maka siswa tentunya akan lebih sulit untuk menyelesaikannya. Senada dengan hal tersebut, menurut Hudojo (2000) suatu soal atau pertanyaan disebut permasalahan bergantung kepada pengetahuan yang pernah siswa dapatkan. Apabila siswa memiliki keterbatasan pengetahuan awanya tentunya soal dalam matematika merupakan sebuah permasalahan yang harus diselesaikan.

Penyelesaian masalah matematika tidak terlepas dari muatan kognitif yang diproses oleh siswa. Siswa yang tidak memiliki pengetahuan awal yang cukup mengalami permasalahan di muatan kognitif (Retnowati, 2012; Sweller, Areys, \& Kalyuga, 2011). Lain halnya dengan siswa yang memiliki keterbatasan pengetahuan awal, muatan kognitif siswa yang didapatkan sangat berat. Cognitive load theory membedakan muatan kognitif atau cognitive load menjadi tiga macam yaitu extraneous cognitive load, intrinsic cognitive load, dan germane cognitive load (Paas, Tuovinen, Tabbers, \& Van Gerven, 2010). Muatan kognitif yang menghalangi proses memahami atau belajar sesuatu hal disebut dengan extraneous cognitive load, sehingga sumber dari muatan ini perlu diminimalisir (Mwangi \& Sweller, 1998; Sweller et al., 2011). Sementara itu, muatan kognitif yang hadir secara alamiah bersumber dari kompleksitas materi yang sedang dipelajari disebut dengan intrinsic cognitive load. Oleh karena itu, struktur kognitif sebaiknya difokuskan dalam mengelola intrinsic cognitive load yaitu dengan meningkatkan siswa untuk berpikir produktif. Muatan kognitif yang menghasilkan upaya produktif untuk mengkonstruk pengetahuan baru oleh cognitive load theory disebut germane cognitive load.

Strategi pembelajaran yang efektif adalah strategi pembelajaran yang meminimalisir extraneous cognitive load sehingga siswa dapat mengatur dengan baik intrinsic cognitive load dan mengefektifkan germane cognitive load (Ward \& Sweller, 2009). Apabila siswa mengalami muatan kognitif tinggi khususnya extraneous cognitive load, maka siswa akan mengalami kesulitan dalam menerima materi pembelajaran (Retnowati, 2008). Pembelajaran yang efektif adalah pembelajaran yang mengkombinasikan pemecahan masalah dengan memberikan contoh kerja yang dikenal dengan strategi pembelajaran worked example (Renkl, Atkinson, Maier, \& Staley, 2002).

Pada prinsipnya strategi worked example merupakan pembelajaran problem solving (Renkl et al., 2002). Meminimalisir muatan kognitif siswa, perlu strategi permbelajaran yang dapat meringankan muatan kognitif proses akuisisi siswa dalam mengonstruk pengetahuan barunya. Worked example telah terbukti lebih baik dibandingkan dengan strategi problem solving untuk menyelesaikan pemecahan masalah dengan memberikan contoh langkah demi langkah secara sistematis dan rinci (Tarmizi \& Sweller, 1988) sehingga strategi worked example dinilai sangat tepat untuk meminimalisir muatan kognitif pada proses akuisisi siswa. Dengan diberikan contoh yang sama (isomorphic problem) untuk masalah yang diselesaikan akan membantu siswa dalam meminimalisir muatan kognitif akibat dari proses penyelesaian masalah (Ward \& Sweller, 2009).

Pembuatan lembar kerja worked example sebaiknya menghindari split attention dan redundance effect agar tidak mengakibatkan extraneous cognitive load (Kalyuga, 2011). Split attention effect adalah suatu rancangan yang terkait beberapa sumber yang disajikan terpisah (Chandler \& Sweller, 1992). Sedangkan redundance effect akan terjadi apabila beberapa informasi yang sama diberikan secara bersamaan akan tetapi tidak memberikan informasi satu sama lain (Sweller, 2006).

Worked example adalah strategi pembelajaran pemecahan masalah yang sangat efektif dalam meminimalisir muatan kognitif siswa. Worked example merupakan strategi yang digunakan untuk siswa yang masih memiliki kemampuan awal yang terbatas (limited prior knowledge) (Sweller et al., 2011). Menurut Sweller et al. (2011) worked example secara efisien meminjamkan pengetahuan prasyarat yang diperlukan untuk memecahkan masalah kepada siswa. Dengan menggunakan langkah demi langkah 
yang telah disediakan, siswa lebih mudah mengkonstruk pengetahuannya dalam menyelesaikan permasalahan. Senada dengan pendapat tersebut, Clark, Nguyen, dan Sweller (2006) menyatakan worked example adalah suatu strategi pembelajaran yang dirancang untuk mengurangi muatan kognitif siswa yang disebabkan oleh beberapa bentuk muatan kognitif akibat proses pemecahan masalah. Dengan strategi pembelajaran worked example, semua permasalahan dan penyelesaian langkah demi langkah diberikan secara detail sehingga siswa lebih fokus dalam memahami konsep yang mendasari pemecahan masalah.

Untuk meningkatkan kemampuan pemahaman konsep dalam memecahkan masalah matematika salah satu upaya yang dilakukan oleh guru adalah menerapkan pembelajaran yang membuat siswa berinteraksi dan bersosial dengan siswa lainnya. Kebersamaan sosial sering adaptif dan mungkin berkembang sebagai aspek yang berguna dalam kelompok (Kameda \& Tindale, 2006). Kelompok terbentuk dari kekeluargaan, belajar dalam kelas, sosial dalam grup pertemanan dan berkomunikasi, serta sering berkerja di dalam tim (Tindale, Cristine, Amanda, \& Katharina, 2012). Webb (1991) menyarankan agar pemberian penjelasan kepada anggota kelompok oleh teman kelompok lainnya tidak hanya sekedar bertukar gagasan atau ide tetapi juga mendorong penemuan unuk mendasari sebuah prinsip. Proses memberikan penjelasan dapat mendorong siswa yang memberi penjelasan tentang mengklarifikasi, mereorganisasi dan menyelesaikan materi serta mengembangkan perspektif baru (Webb, 1991). Proses menerima penjelasan dapat membantu siswa yang belajar untuk mengklarifikasi serta mengumpulkan informasi dari penjelasan siswa lain. Webb (1991) menyebut efek memberikan penjelasan sebagai fasilitas kognitif. Bertukar penjelasan dalam kelompok kecil harus memenuhi syarat tertentu untuk mencapai pembelajaran aktif. Harus ada kondisi yang memastikan terjadi interaksi positif denga siswa memiliki kesempatan yang sama dalam membantu siswa lainnya dan harus konsisten (Retnowati, 2012). Melalui kegiatan diskusi, siswa dapat mengelola informasi dengan sendirinya. Akan tetapi belajar bersama tidak semua digolongkan sebagai kolaboratif. Apabila siswa di dalam kelompok tidak saling menyumbangkan ide, gagasan, pikiran, dan tanggung jawab terhadap pencapaian hasi belajar secara kelompok ataupun individu.

Kolaboratif tidak selalu baik, menempatkan pembelajar ke dalam kelompok dan memberikan tugas tidak menjamin mereka akan bekerjasama dalam keterlibatan proses pembelajaran kolaboratif yang efektif (Soller, 2001). Namun kolaborasi terkontrol dalam lingkungan belajar juga bukan jaminan untuk keberhasilan. Kinerja kelompok dengan skor individu (nominal) dalam banyak kasus, kinerja individu lebih rendah daripada kinerja kelompok, yang berarti kemampuan mengingat siswa kelompok apabila dilakukan secara individu akan terlihat kurang (Kirschner, Pass, \& Kirschner, 2009).

Hasil yang berbeda ditemukan ketika tugas yang digunakan adalah pemecahan masalah. Ketika siswa harus bekerja dalam mencari solusi dengan cara menghubungkan informasi satu dengan yang lain, kolaboratif lebih mengungguli individu (Laughlin, Bonner, \& Miner, 2002; Laughlin, Hatch, Silver, \& Boh, 2006). Penelitian dimana individu dan kelompok dibandingkan terkait daya ingat atau kinerja dalam pemecahan masalah menunjukkan bahwa pembelajaran individu lebih unggul daripada pembelajaran kelompok dengan tugas yang sederhada. Sebaliknya, kolaboratif akan lebih unggul dibanding individu apabila pemecahan masalah bersifat relatif kompleks (Kirschner et al., 2009).

Pembelajaran kolaboratif juga perlu mempertimbangkan tugas yang akan diberikan, dimana banyak pemberian tugas yang tidak tepat di dalam kolaboratif seperti tugas membuat puisi (Tindale et al., 2012) dan tanpa sumber yang tepat, mungkin desain untuk grup akan gagal (Hackman, 1998). Jenis tugas juga menjadi faktor penting dalam mementukan apakah kolaborasi bermanfaat atau tidak (Kirschner et al., 2009). Webb (1991) menyarankan siswa yang memiliki kemampuan yang sedang sebaiknya membentuk grup yang homogen bukan heterogen. Apabila membetuk grup heterogen, siswa yang memiliki kemampuan lebih tinggi akan mendominasi proses penyelesaian masalah dan menimbulkan ketergantungan pada teman sekelompoknya. Sedangkan Swing dan Peterson (1982) menemukan grup yang heterogen tidak dapat memfasilitasi siswa berkemampuan sedang dikarenakan seseorang yang memiliki kemampuan sedang akan kalah aktif dengan siswa yang memiliki kemampuan tinggi akan lebih banyak menjelaskan terhadap siswa lainnya dan siswa yang memiliki kemapuan rendah dengan tanya dia akan selalu bertanya apa yang dia tidak diketahui.

Pembagian kelompok juga harus perlu diperhatikan. Ada sedikit penelitian yang mencakup ukuran dan interaksi kelompok yang ideal. Sebagian besar penelitian berlaku untuk kelompok yang memiliki 4 sampai 5 anggota di dalam kelompok (Johnson \& Johnson, 1994). Hal ini sudah di yakini secara luas bahwa semakin kecil ukuran kelompok semakin tinggi kesempatan bagi setiap anggota untuk 
berpartisipasi secara aktif. Sedangkan ukuran kelompok semakin besar, peran aktif dalam individu tiap kelompok akan semakin kecil (Retnowati, 2012). Kelebihan dalam strategi kolaboratif ini menurut Hill dan Hill (1993) yaitu: (1) prestasi belajar lebih tinggi; (2) pemahaman lebih mendalam; (3) belajar lebih menyenangkan; (4) mengembangkan keterampilan kepemimpinan; (5) meningkatkan sikap positif; (6) meningkatkan harga diri; (7) belajar secara inklusif; (8) merasa saling memiliki; dan (9) mengembangkan keterampilan masa depan.

Kolaboratif sebaiknya mengikutsertakan siswa sebagai rekan pembelajar (Zajac \& Hartup, 1997) dan jangan hanya satu siswa yang membantu yang lain. Di dalam kolaboratif diharuskan adanya interaksi oleh siswa untuk bertukar pikiran. Komunikasi yang mengarah pada kognitif bersama dan pembangunan model mental bersama, diidentifikasi sebagai aspek kunci dalam kolaboratif (Barron, 2003). Komunikasi sangat penting ketika membutuhkan informasi untuk berhasil memecahkan permasalahan yang didistribusikan antara anggota kelompok, sehingga semua anggota memiliki informasi penting yang berbeda (Kirschner et al., 2009). Agar kolaboratif dapat dilaksanakan secara efektif, guru dan siswa saling beradaptasi sehingga kondisi kelas menjadi normal (Blacthford, Peter, Baines, \& Maurice, 2003). Pembelajaran kolaboratif juga menekankan siswa agar dapat memahami materi pelajaran dengan menyenangkan (Primadiati \& Djukri, 2017). Model pembelajaran kolaboratif memberikan peluang untuk saling belajar pada masing-masing anggota kelompok sehingga dapat mempengaruhi motivasi teman kelompoknya (Sato, 2012).

Berdasarkan uraian latar belakang dan kajian teori yang telah dikemukakan, maka penelitian ini bertujuan untuk mendeskripsikan dan membandingkan efektivitas strategi pembelajaran worked example dan problem solving dengan strategi pengelompokan siswa (kolaboratif dan individual) ditinjau dari kemampuan pemecahan masalah dan cognitive load. Adapun hipotesis penelitian yang akan diuji pada penelitian ini yaitu: (1) strategi worked example efektif dibandingkan dengan strategi problem solving ditinjau dari kemampuan pemecahan masalah dan cognitive load; (2) strategi pengelompokan belajar siswa secara kolaboratif efektif dibandingkan dengan strategi pengelompokan belajar secara individu ditinjau dari kemampuan pemecahan masalah dan cognitive load; dan terdapat efek interaksi antara strategi pengelompokan dan strategi pembelajaran ditinjau dari kemampuan pemecahan masalah dan cognitive load.

\section{METODE}

\section{Desain Experimen}

Penelitian ini menggunakan desain faktorial $2 \times 2$ dengan pendekatan pembelajaran problem solving (PS) vs. worked example (WE) dan setting pembelajaran siswa dengan kolaboratif vs. individual sehingga terdapat empat kelompok yang terlibat, yaitu: (1) kolaboratif dengan strategi worked example; (2) kolaboratif dengan strategi problem solving; (3) individual dengan strategi worked example; dan (4) individual dengan strategi problem solving.

\section{Partisipan}

Sejumlah 88 siswa kelas VIII di SMP swasta di Yogyakarta berpartisipasi secara sukarela dalam penelitian ini. Karena terdapat ketidaklengkapan data, maka data yang dianalisis hanya melibatkan 64 siswa. Rincian jumlah siswa untuk masing-masing kelompok dalam penelitian ini disajikan pada Tabel 1.

Tabel 1. Jumlah Siswa di Setiap Kelompok

\begin{tabular}{lcc}
\hline & Worked example & Problem Solving \\
\hline Kolaboratif & $16(7 \mathrm{M}, 9 \mathrm{~F})$ & $16(9 \mathrm{M}, 7 \mathrm{~F})$ \\
Individual & $16(10 \mathrm{M}, 6 \mathrm{~F})$ & $16(8 \mathrm{M}, 8 \mathrm{~F})$ \\
Total & 32 & 32 \\
\hline
\end{tabular}

$\mathrm{M}=$ Male, $\mathrm{F}=$ Female

Karakter kemampuan siswa SMP tersebut berada pada kategori rendah hingga sedang. Hal ini dapat dilihat pada rangking sekolah (dari nilai TPM kelas 3 tingkat kabupaten) di Yogyakarta, dimana sekolah tersebut berada pada urutan 111 dari 133 sekolah. Kelas VIII A memiliki rata-rata 52,01 dengan jumlah siswa yang tuntas KKM 0 siswa dan yang tidak tuntas 30 siswa. Kelas VIII C memiliki rata-rata 39,11 dengan jumlah siswa tuntas KKM 0 siswa dan siswa yang tidak tuntas 28 siswa. Kelas VIII D 
memiliki rata-rata 40,48 dengan jumlah siswa yang tuntas KKM 0 siswa dan yang tidak tuntas 30 siswa. Pelaksanaan penelitian ini dilaksanakan pada bulan Februari - Maret 2018. Kurikulum yang diterapkan sekolah untuk siswa kelas VIII masih menggunakan Kurikulum Tingkat Satuan Pendidikan (KTSP).

\section{Materi}

Penelitian ini mengambil materi bagian dari Geometri yaitu hubungan sudut pusat, panjang busur, dan luas juring. Berdasarkan penelitian-penelitian sebelumnya, daya serap materi geometri siswa masih rendah dikarenakan kompleksitas geometri sangat tinggi sehingga menjadi pertimbangan peneliti untuk mengambil materi yang berhubungan dengan geometri. Peneliti ingin mengambil materi tentang luas juring, panjang busur, dan hubungan sudut pusat, panjang busur, dan luas juring pada materi lingkaran. Peneliti mengatur intrinsic cognitive load materi pembelajaran dalam penelitian ini sehingga tingkat kompleksitas materi ini disesuaikan dengan karakteristik siswa sampel dalam penelitian ini. Pemilihan materi juga diatur, sehingan pada saat pelaksanaan penelitian partisipan belum pernah mempelajari atau menyelesaikan masalah-masalah matematika yang diberikan oleh peneliti.

\section{Prosedur}

Penelitian ini mengambil tiga kelas dari empat kelas yang sudah dipilih secara acak. Penelitian ini menggunakan empat fase: fase prasyarat, fase pendahuluan, fase akuisisi, dan fase tes. Data diambil melalui tes yang dilaksanakan pada pertemuan keenam setelah lima kali tatap muka. Rincian pelaksanaan penelitian disajikan pada Tabel 2 .

\section{Tabel 2. Pencapaian Kompetensi}

\begin{tabular}{|c|c|c|}
\hline Pertemuan pertama $(2 \times 40$ menit $)$ & Fase Prasyarat & Mengenal kembali materi prasyarat \\
\hline Pertemuan kedua $(2 \times 40$ menit $)$ & Fase & Memahami sudut pusat dan sudut keliling \\
\hline Pertemuan ketiga $(2 \times 40$ menit $)$ & Pendahuluan & Memahami masalah berkaitan dua tali busur \\
\hline Pertemuan keempat ( $2 \times 40$ menit $)$ & Fase Akuisisi & $\begin{array}{l}\text { Menyelesaikan masalah yang berkaitan Panjang busur } \\
\text { dan luas juring }\end{array}$ \\
\hline Pertemuan kelima $(2 \times 40$ menit $)$ & & $\begin{array}{l}\text { Menyelesaikan masalah yang berkaitan dengan } \\
\text { hubungan sudut pusat, Panjang busur, dan luas juring }\end{array}$ \\
\hline Pertemuan Keenam ( $2 \times 40$ menit $)$ & Fase Tes & $\begin{array}{l}\text { Materi Luas juring, panjang busur, dan hubungan sudut } \\
\text { pusat, panjang busur, dan luas juring. }\end{array}$ \\
\hline
\end{tabular}

Pada fase akuisisi, peneliti memberikan strategi worked example kepada siswa yang dipilih secara random disetiap kelasnya. Siswa disetiap kelas akan dibagi menjadi 4 kelompok yaitu Kolaboratif-WE, Kolaboratif-PS, Individual-WE, dan Individual-PS secara random.

\section{Fase Prasyarat}

Pada fase ini seluruh siswa memulai dengan belajar materi prasyarat pada Tabel 3. Materi prasyarat ini dilaksanakan sebelum fase akuisisi dilaksanakan. Materi prasyarat ini sebagai pemahaman yang harus dimiliki oleh siswa untuk melalui proses fase akuisisi.

Tabel 3. Materi Prasyarat

\begin{tabular}{cl}
\hline No. & \multicolumn{1}{c}{ Materi Prasyarat } \\
\hline 1. & Besar sudut yang saling bersuplemen adalah $180^{\circ}$ \\
2. & Besar sudut yang saling berkomplemen adalah $90^{\circ}$ \\
3. & Sudut pusat $=2 \times$ sudut keliling \\
4. & Theorema Pythagoras \\
5. & Besar 2 sudut yang saling bertolak belakang adalah sama \\
6. & Keliling lingkaran \\
7. & Luas lingkaran \\
8. & Jumlah sudut-sudut dalam segitiga adalah $180^{\circ}$ \\
\hline
\end{tabular}

Tujuan materi prasyarat ini untuk mengingatkan kembali pengetahuan yang telah mereka dapatkan sebelumnya. Materi prasyarat sebagai dasar dari pengetahuan baru yang akan mereka konstruk. Pada fase ini siswa mengingat kembali materi sebelumnya dengan cara pembelajaran secara langsung yaitu mengukur sudut dalam segitiga, sudut saling berkomplemen dan bersuplemen. 


\section{Fase Pendahuluan}

Fase pendahuluan ini terdiri dari tiga bagian yaitu: (1) materi prasyarat; (2) memahami sudut pusat dan sudut keliling; (3) memahami masalah berkaitan dengan dua tali busur. Pada materi prasyarat sudah dijelaskan pada Tabel 3. Pada materi memahami sudut pusat dan sudut keliling merupakan materi yang baru didapatkan oleh siswa dan merupakan pengetahuan baru bagi siswa. Meskipun materi ini merupakan materi yang baru bagi siswa, peneliti tidak menggunaan strategi worked example dikarenakan kompleksitas materi tersebut tidak banyak. Worked example digunakan untuk materi yang tingkat kompleksitasnya tinggi. Pada materi ketiga, memahami masalah berkaitan dengan dua tali busur, penulis juga tidak menggunakan strategi worked example dikarenakan kompleksitas materi masih belum terlalu luas dan tinggi. Ketiga materi pendahuluan ini merupakan syarat siswa untuk mendapatkan materi pada fase akuisisi.

\section{Fase Akuisisi}

Fase akuisisi merupakan fase siswa untuk mendapatkan materi baru yang cukup kompleks. Pada fase ini siswa dituntut untuk memecahkan permasalahan yang membutuhkan penalaran. Materi fase pendahuluan ini digunakan untuk memecahan permasalahan pada proses akuisisi materi baru bagi siswa. Pada fase ini siswa dikelompokkan menjadi empat bagian dengan cara random sesuai dengan desain penelitian.

Seal: Tentukan Panjang busur. BD dan luas juring, BOD

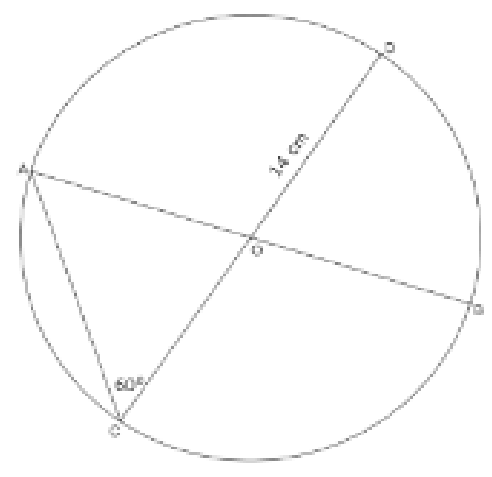

Solusi:

Langkah 1.Cari ukuran sudut pusat yang menghadap busur BD

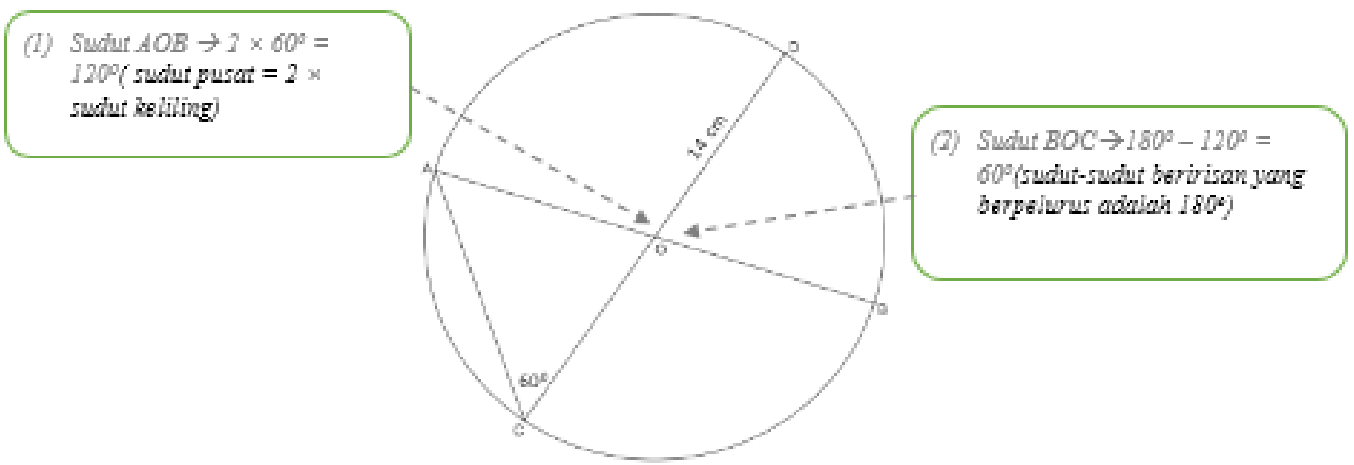

Langkah 2. Cari panjang busur BD dan luas juring BOD

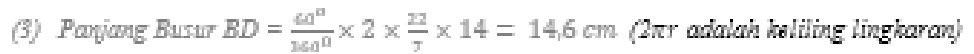

(4) Lwas Juring $B O D=\frac{60^{\circ}}{260^{\circ}} \times \frac{22}{7} \times 14 \times 14=102,6 \mathrm{~cm}^{2}\left(\mathrm{sr}^{2}\right.$ adaiah iwas lingharan)

Gambar 1. Contoh LKS Worked Example 
Setiap bagian worked example dan problem solving akan diberikan LKS yang berbeda. Perbedaan tersebut terletak pada pemberian langkah dan tidaknya. LKS worked example (lihat Gambar 1) menyediakan contoh penyelesaian berdasarkan langkah-langkah sehingga siswa dapat menyelesaikan masalah dengan cara belajar dengan contoh. Tujuan penyelesaian masalah pada Gambar 1 adalah menentukan panjang busur, luas juring, dan hubungan sudut pusat, panjang busur, dan luas juring. Pada LKS worked example, terdapat contoh yang memuat langkah-langkah penyelesaian masalah yang ditulis berwarna hitam dan warna abu-abu. Langkah yang berwana hitam merupakan prosedur penyelesaian masalah serta hasil penyelesaian masalah sedangkan warna abu-abu merupakan keterangan yang menginformasikan siswa tentang prosedur penyelesaian.

Alokasi waktu yang digunakan untuk mengerjakan LKS adalah 45 menit. Sedangkan pada startegi problem solving tidak menyediakan contoh penyelesaian. Siswa yang mendapatkan bagian kolaboratifworked example diinstruksikan memahami contoh penyelesaian masalah dengan cara berdiskusi, berinteraksi, memecahkan masalah, dan menjawab permasalahan dengan teman sekelompoknya.

Pembagian LKS pada setiap kelompok individu dan kolaboratif sama yaitu masing-masing mendapatkan 1 LKS. Individu akan mendapatkan LKS untuk diri sendiri sedangkan kolaboratif mendapatkan 1 LKS untuk 1 kelompok sehingga meraka diharuskan berdiskusi dalam mempelajari langkah-langkah penyelesaian masalah.

Awal kegiatan pembelajaran, guru mengingatkan kembali materi yang sudah didapat oleh siswa pada pertemuan sebelumnya selama 10 menit. Kemudian siswa yang mendapatkan strategi worked example dan problem solving dibagi menjadi dua tempat. Dikarenakan peneliti mengambil tiga kelas yaitu kelas $8 \mathrm{~A}, 8 \mathrm{~B}$, dan $8 \mathrm{C}$, maka ada dua kelas yang digabung menjadi satu waktu yaitu kelas $8 \mathrm{~A}$ dan $8 \mathrm{D}$. Siswa kelas $8 \mathrm{~A}$ dan $8 \mathrm{D}$ yang mendapatkan worked example berada di kelas $8 \mathrm{~A}$ sedangkan problem solving berada di kelas $8 \mathrm{D}$. Sedangkan kelas $8 \mathrm{C}$ yang mendapatkan worked example berada di dalam kelas, sedangkan problem solving berada di mushola. Proses akuisisi berlangsung 45 menit dan sudah termasuk guru menjelaskan jawaban yang benar terhadap siswa. Selama 45 menit siswa diminta menyelesaikan masalah yang telah disediakan. Pada penelitian ini, peneliti menggunakan isomorphic problem (konteks dan prosedur sama) antara penyelesaian permasalahan di LKS dengan permasalahan pada instrumen tes (lihat Gambar 2). Keduanya memiliki kesamaan dalam konteks dan prosedur penyelesaian. Siswa yang mengerjakan dengan menggunakan contoh akan lebih mudah dalam menyelesaikan permasalah yang diberikan dan meminimalisir muatan kognitif dalam menyelesaikan permasalahan.

2. Soal :

Tentukan panjang busur BD dan luas juring BOD (Javaban boleh dituis di daian gambar)

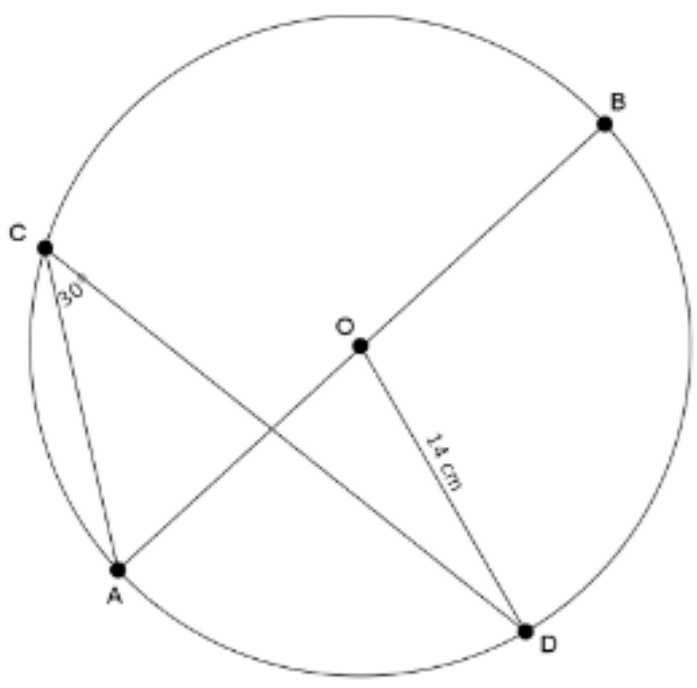

Solusi :

Gambar 2. Permasalahan dalam Instrumen Tes 
Pada akhir kegiatan pembelajaran, guru menjelaskan jawaban yang benar serta memberikan penjelasan yang relevan berdasarkan contoh-contoh yang telah diberikan dan memberikan umpan balik kepada siswa.

\section{Fase Tes}

Fase tes ini digunakan untuk mengukur pemahaman siswa dalam menyelesaikan masalah setelah siswa melalui fase akuisisi. Permasalahan yang ada di fase tes dibuat sama dengan permasalahan pada fase akuisisi dengan tingkat kompleksitas yang sama. Pengukuran melalui tes ini melibatkan aspek numeric. Kemampuan numeric siswa dari mencari sudut pusat kemudian menyelesaikan masalah sampai memasukkan ke dalam rumus. Pada tes ini terdiri dari 9 permasalahan yang harus diselesaikan oleh siswa. Adapun kisi-kisinya dapat dilihat pada Tabel 4. Siswa menyelesaikan soal tes maksimal 60 menit. Di dalam kelas masing-masing, siswa menjawab semua permasalahan untuk dicari penyelesaian dengan pengawasan dari guru sehingga diharapkan nilai tes benar-benar asli berdasarkan pemahaman siswa.

Tabel 4. Kisi-Kisi Instrumen Tes

\begin{tabular}{llc}
\hline No & Indikator & Soal \\
\hline 1 & Menunjukkan pemahaman, penggunaan strategi dan prosedur, dan komunikasi yang tepat & 1,2, \\
& $\begin{array}{l}\text { dalam proses pemecahan masalah yang berkaitan dengan panjang busur } \\
2\end{array}$ & $\begin{array}{l}\text { Menunjukkan pemahaman, penggunaan strategi dan prosedur, dan komunikasi yang tepat } \\
\text { dalam proses pemecahan masalah yang berkaitan dengan luas juring }\end{array}$ \\
3 & $\begin{array}{l}\text { Menunjukkan pemahaman, penggunaan strategi dan prosedur, dan komunikasi yang tepat } \\
\text { dalam proses pemecahan masalah yang berkaitan dengan hubungan sudut pusat, panjang busur, }\end{array}$ & 7,8, \\
& dan luas juring. & 9 \\
\hline
\end{tabular}

Aspek lain yang diukur yaitu cognitive load. Cognitive load diukur berdasarkan muatan kognitif siswa dalam menyelesaikan permasalahan tiap soal tes. Skala cognitive load terdiri dari satu sampai 9 (sangat-sangat mudah sampai sangat-sangat susah) dan siswa diinstruksikan melingkari skala sesuai tingkat kesulitan soal. Skala tersebut dapat dilihat pada Gambar 3.

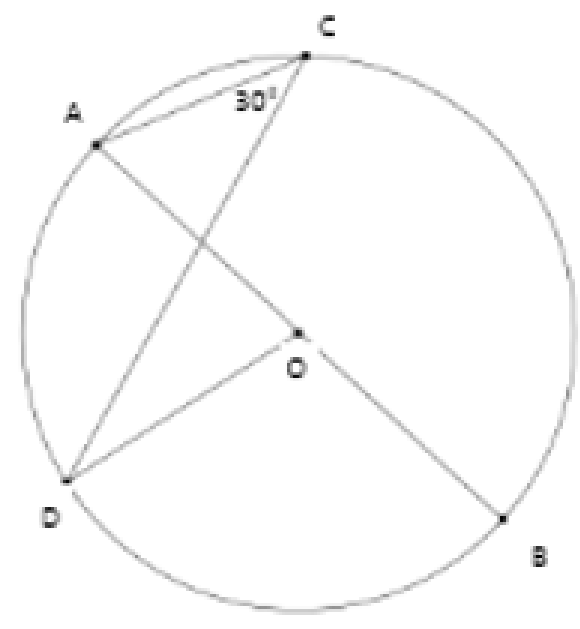

Tentukan panjeng busur DB jika jeri-jari adalah $14 \mathrm{~cm}$

Jatraban :

Soberspa mudah atau salit mengerjakan soal diates? Lingicallah salah satu no dibawhi ini

\begin{tabular}{l|l|l|l|l|l|l|l|l}
1 & 2 & 3 & 4 & 5 & 6 & 7 & 8 & 9
\end{tabular}




\section{Validitas dan Reliabilitas Instrumen}

Validitas instrumen dibuktikan melalui expert judgement yang melibatkan dosen ahli dari Universitas Negeri Yogyakarta. Instrumen direvisi berdasarkan masukan ahli. Reliabilitas instrumen diestimasi menggunakan formula Cronbach's Alpha dengan bantuan software SPSS. Pada estimasi reliabilitas instrumen tes ini didapat nilai Cronbach's alpha adalah 0,847. Berdasarkan nilai tersebut, instrumen tes pada penelitian ini cukup handal untuk diujikan.

\section{Analisis Data}

Analisis data dilakukan secara deskriptif dan inferensia. Analisis deskriptif dilakukan untuk mendeskripsikan kemampuan pemecahan masalah dan cognitive load siswa setelah mendapat perlakuan. Analisis inferensia dilakukan untuk menguji hipotesis penelitian. Pengujian hipotesis dalam penelitian dilakukan pada taraf signifikansi $95 \%(\alpha=0,05)$.

\section{HASIL DAN PEMBAHASAN}

\section{Hasil}

Kemampuan Pemecahan Masalah

Penilaian kemampuan pemecahan masalah ini didasarkan kepada nilai tes. Secara deskriptif, jika ditinjau dari strategi pembelajaran, nilai rata-rata kemampuan pemecahan masalah siswa yang belajar dengan worked example lebih tinggi $(M=0,523 ; S D=0.67)$ dibandingkan dengan siswa yang belajar dengan problem solving $(M=0,36 ; S D=0,358)$. Sedangkan jika ditinjau dari strategi pengelompokan, nilai rata-rata kemampuan pemecahan masalah siswa yang belajar dengan strategi kolaboratif nilai lebih tinggi $(M=0,488 ; S D=0,457)$ dibandingkan dengan siswa yang belajar secara individu $(M=0,395$; $S D=0,614)$.

Hasil analisis inferensia terkait kemampuan pemecahan masalah menunjukkan bahwa tidak ada perbedaan yang signifikan antara pembelajaran worked example dan problem solving $\left(F_{(1,64)}=1,446 ; p\right.$ $=0,234)$. Nilai signifikasi yang didapat adalah 0,234 dimana $p>0,05$, sehingga $\mathrm{H}_{0}$ diterima. Demikian juga antara strategi pengelompokan individu dan kelompok $\left(F_{(1,64)}=0,466 ; p=0,497\right)$, dimana nilai $p$ $>0,05$, sehingga $\mathrm{H}_{0}$ diterima, maka tidak ada perbedaan signifikan kemampuan pemecahan masalah antara siswa yang memperoleh strategi pengelompokan individu dan kelompok.

\section{Cognitive Load}

Secara deskriptif, siswa yang belajar dengan worked example mengalami cognitive load yang lebih rendah $(M=7,16 ; S D=1,26)$ dibandingkan dengan siswa yang belajar dengan problem solving $(M=7,78 ; S D=0,915)$. Hasil analisis inferensia menunjukkan bahwa tidak ada perbedaan signifikan cognitive load antara siswa yang belajar secara kolaboratif dan individu $\left(F_{(1,64)}=0,001 ; p=0,970\right)$. Sedangkan ditinjau dari strategi pembelajaran, hasil analisis menunjukkan bawa ada perbedaan yang signifikan antara siswa yang belajar dengan strategi worked example dan problem solving $\left(F_{(1,64)}=\right.$ 5,301; $p=0,025$ ). Hasil analisis bahwa nilai $\eta_{p}{ }^{2}=0.081$, dengan kata lain, sebanyak $8,1 \%$ (kategori sedang) perbedaan cognitive load dipengaruhi oleh strategi pembelajaran yang digunakan.

\section{Pengarus Interaksi antara Strategi Pembelajaran dan Pengelompokan terhadap Cognitive Load}

Hasil analisis menunjukkan bahwa terdapat efek interaksi yang signifikan antara pengelompokan dan strategi pembelajaran ditinjau dari cognitive load $\left(F_{(1,64)}=4,720 ; p=0,034 ; \eta_{p}{ }^{2}=0.073\right)$. Hasil tersebut juga menunjukkan bahwa sebesar $7,3 \%$ perbedaan cognitive load disebabkan hasil interaksi antara variabel pengelompokan dan strategi pembelajaran. Gambar 4 mendeskripsikan adanya efek interasi terhadap cognitive load tersebut. 


\section{Estimated Marginal Means of CL}

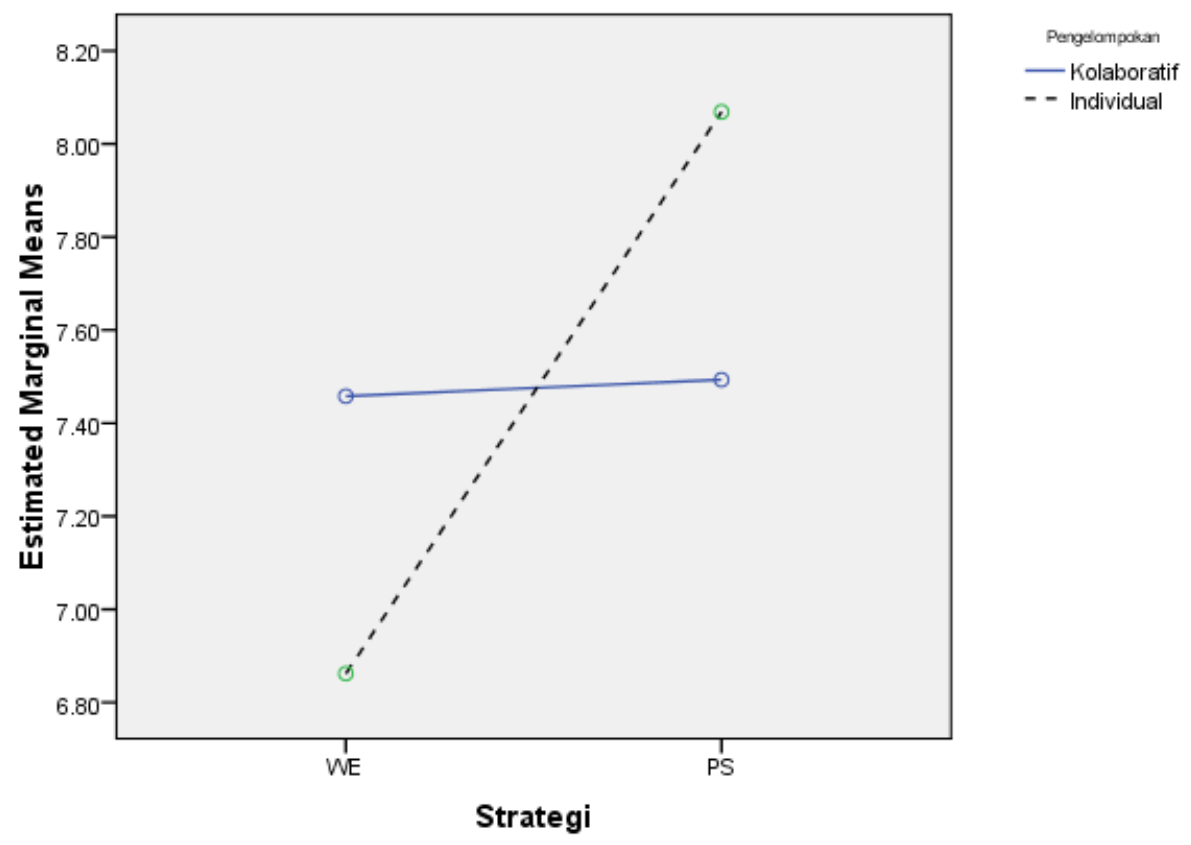

Gambar 4. Grafik Interaksi Strategi Pengelompokan dan Strategi Pembelajaran

Pada Gambar 4 terlihat bahwa adanya efek interaksi ketika siswa belajar dengan kolaboratif-WE, Individual-WE, kolaboratif-PS, dan individual-PS. Siswa yang belajar dengan Individual-WE memiliki cognitive load yang rendah. Lain halnya dengan siswa yang belajar dengan individual-PS memiliki cognitive load yang besar. Pada pembelajaran kolaboratif, antara siswa WE dan PS tidak memiliki perbedaan cognitive load yang cukup besar. Karena pada strategi individual memiliki perbedaan yang cukup besar maka terjadi efek interaksi tersebut.

Karena ada efek interaksi, maka dilakukan analisis lanjutan yaitu simple effect test (t-test). Hasil analisis ini menunjukkan bahwa ketika siswa belajar secara kolaboratif, tidak ada perbedaan cognitive load antara strategi worked example dan problem solving $(t=0,10 ; p=0,921)$. Sedangkan ketika siswa belajar secara individu, terdapat perbedaan yang signifikan cognitive load antara strategi worked example dengan problem solving $(t=2,93 ; p=0,006)$, dimana siswa dengan worked example mengalami cognitive load yang lebih rendah $(M=6,86 ; S D=1,46)$ dibandingkan siswa yang menggunakan pembelajaran problem solving $(M=8,06 ; S D=0,74)$.

\section{Pembahasan}

Hasil penelitian menunjukkan bahwa efektivitas pembelajaran dengan strategi worked example relatif sama dengan strategi problem solving ditinjau dari kemampuan pemecahan masalah dan cognitive load. Walaupun nilai rata-rata kemampuan pemecahan masalah strategi worked example lebih tinggi dibandingkan dengan rata-rata kemampuan pemecahan masalah strategi problem solving dan rata-rata cognitive load pada strategi worked example lebih rendah dari probem solving. Strategi worked example masih belum efektif dikarenakan siswa masih belum begitu mengenal betul belajar dengan contoh serta pada proses penelitian siswa yang mendapatkan kelompok kolaboratif tidak setiap siswa mendapatkan contoh penyelesaian sehingga menimbulkan ketergantungan teman kelompoknya. Pada proses fase tes, ketergantungan siswa ini berdampak kepada nilai siswa yang tidak begitu baik. Pada fase akuisisi, siswa yang bergantung pada teman kelompok melewatkan fase tersebut sehingga pada fase tes siswa sulit untuk memecahkan masalah. Hal ini relevan dengan hasil penelitian sebelumnya, Retnowati et al. (2010) menyatakan bahwa hasil siswa yang mendapatkan kolaboratif worked example mendapatkan lebih tinggi daripada siswa yang mendapatkan kolaboratif problem solving. Dalam penelitian Retnowati et al. (2010) menunjukkan bahwa worked example dapat bermanfaat dalam lingkungan pembelajaran kolaboratif. Hasil ini juga sesuai dengan temuan sebelumnya (Cooper \& Sweller, 1987; Mwangi \& Sweller, 1998; Sweller \& Cooper, 1985) dimana penelitian-penelitian yang dilakukan tersebut menunjukkan bahwa contoh-contoh kerja mengurangi muatan kognitif dibandingkan dengan pemecahan masalah. 
Moll (1993) menyatakan bahwa banyak penelitian yang mampu menjawab bahwa pembelajaran kolaboratif terbukti sangat efektif dalam menginduksi perkembangan kognitif siswa. Akan tetapi pembelajaran dengan strategi pengelompokan siswa yaitu kolaboratif masih belum begitu efektif dibandingkan dengan individual ditinjau dari kemampuan pemecahan masalah dan cognitive load. Walaupun nilai rata-rata kemampuan pemecahan masalah dengan kolaboratif lebih tinggi daripada individual dan muatan kognitif dengan kolaboratif lebih sedikit dibandingkan dengan individual. Hal ini senada dengan penelitian Kirschner et al. (2009) menyatakan bahwa tidak ada manfaat yang signifikan ditemukan pada masalah dalam menyelesaikan masalah. Kegagalan untuk menemukan efek juga telah diperoleh oleh peneliti lain (Mevarech, 1985; Saleh, Lazonder, \& de Jong, 2007; Webb, 1991). Kirschner et al. (2009) yang menyatakan siswa yang belajar dengan kelompok akan lebih efektif dalam fase akuisisi dikarenakan siswa dapat memanfaatkan satu sama lain untuk memproses kapasitas dengan berbagi beban kognitif dalam memecahkan masalah. Sedangkan siswa yang belajar dengan individu lebih efisien dengan dalam fase tes dikarenakan pada fase akuisisi siswa diharuskan memahami sendiri apa yang dipelajari serta mereka harus memproses semua informasi secara sendiri. Pada penelitian Retnowati et al., (2010) juga menemukan tidak ada efek superior yang ditemukan untuk kerja kelompok dibandingkan dengan individual. Pada kerja kelompok cenderung lebih tinggi daripada individu.

Hasil penelitian juga menunjukkan bahwa tidak ada interaksi antara strategi worked example dan problem solving terhadap pengelompokan siswa kolaboratif dan individual ditinjau dari kemampuan pemecahan masalah. Sedangkan ada interaksi antara strategi worked example dan problem solving terhadap pengelompokan siswa kolaboratif dan individual ditinjau dari cognitive load. Kemudian dilanjutkan dengan uji lanjutan dengan menggunakan simple effect test (t-test). Terlihat bahwa siswa yang belajar dengan kolaboratif tidak ada perbedaan yang signifikan. Sedangkan siswa yang belajar dengan individual terjadi perbedaan yang signifikan terhadap cognitive load.

Hasil penelitian tersebut menunjukkan bahwa strategi pengelompokan siswa kolaboratif masih kurang efektif dibandingkan dengan strategi pengelompokan siswa secara individu ditinjau dari segi kemampuan pemecahan masalah dan cognitive load. Hal ini telah diindikasikan bahwa pemberian satu contoh pada satu kelompok akan mengurangi kerja sama dalam memahami penyelesaian masalah. Selain itu siswa dalam pembelajaran kelompok dituntut harus bekerjasama, menyatukan informasi dari teman kelompok. Akan tetapi, hal tersebut dapat memunculkan spekulasi bahwa tugas interaksi menyebabkan informasi yang berlebih dalam menyelesaikan pemecahan masalah. Seperti yang dijelaskan dalam teori beban kognitif, dalam pemberian contoh perlunya meminimalisir redundace effect. Siswa dalam kondisi ini mendapatkan dua informasi yang sama dari dua sumber yang berbeda. Apabila dalam pemberian contoh memuat reduncace effect, tugas interaksi mungkin memaksa muatan kognitif siswa karena efek redundace dan mengganggu dalam pembelajaran. Interaksi ini mungkin memaksa muatan kognitif yang lebih tinggi bukan untuk menurunkan muatan kognitif (Kirschner et al., 2009). Sedangkan strategi worked example mempunyai keefektifan yang relatif sama dengan problem solving dikarenakan siswa masih belum memahami cara belajar dengan contoh.

\section{SIMPULAN}

Berdasarkan hasil penelitian dan pembehasan dapat disimpulkan bahwa strategi pembelajaran worked example tidak lebih efektif dibandingkan strategi pembelajaran problem solving ditinjau dari kemampuan pemecahan masalah. Ketidakefektifan worked example dikarenakan pada fase akusisi LKS yang diberikan pada siswa yang belajar secara kolaboratif hanya satu, sehingga akses untuk mempelajari LKS tersebut terbatas. Akan tetapi worked example lebih efektif dalam upaya mereduksi cognitive load dibandingkan dengan problem solving. Terkait dengan strategi pengelompokan, pembelajaran kolaboratif tidak lebih efektif dibandingkan dengan pembelajaran individual ditinjau dari kemampuan pemecahan masalah dan cognitive load. Hasil penelitian juga menunjukkan bahwa terdapat efek interaksi antara strategi pengelompokan dan strategi pembelajar dalam mereduksi cognitive load.

Mengacu pada temuan tersebut, disarankan bagi para guru untuk melakukan variasi pembelajaran, salah satunya yaitu dengan menerapkan strategi work example yang dipadukan dengan strategi pengelompokan, sehingga beban kognitif yang dialami siswa ketika belajar matematika dapat dikurangi. Selain itu, perlu dilakukan penelitian sejenis dengan melibatkan populasi dan sampel yang lebih besar, sehingga memungkinkan generalisasi yang lebih luas. 


\section{DAFTAR PUSTAKA}

Barron, B. (2003). When smart groups fail. The Journal of the Learning Sciences, 12(3), 307-359. doi:https://doi.org/10.1207/S15327809JLS1203_1

Blacthford, P., Peter, K., Baines, E., \& Maurice, G. (2003). Toward a social pedagogy of classroom group work. International Journal of Educational Research, 39(1), 153-172. doi:https://doi.org/10.1016/S0883-0355(03)00078-8

Chandler, P., \& Sweller, J. (1992). The split-attention effect as a factor in the design of instruction. British Journal of Education Psychology, 62(2), 233-246. doi:http://dx.doi.org/10.1111/j.20448279.1992.tb01017.x

Chen, O., Kalyuga, S., \& Sweller, J. (2015). The worked example effect, the generation effect and element interactivity. Journal of Educational Psychology, 107(3), 689-704. doi:https://doi.org/10.1037/edu0000018

Clark, R., Nguyen, F., \& Sweller, J. (2006). Efficiency in learning:evidence based guidelinesto manage cognitive load. San Francisco, CA: Pfeiffer.

Cooper, G., \& Sweller, J. (1987). The effects of schema acquisition and rule automation on mathematical problem-solving transfer. Journal of Educational Psychology, 79(4), 347-362. doi:http://dx.doi.org/10.1037/0022-0663.79.4.347

Hackman, J. R. (1998). Why groups don't work. In R. S. Tindale, L. Heath, J. Edwards, E. J. Posavac, F. B. Bryant, Y. Suarez-Balcazar, E. HendersonKing, \& J. Myers (Eds.) Social psychological applications to social issues: Theory and research on small groups (vol. 4, pp. 245-268). New York, NY: Plenum Press.

Hill, S., \& Hill, T. (1993). The collaborative class room. Aguide to co-operative learning. Amadale,Vic: Eleanor Curtain Publishing.

Hudojo, H. (2000). Pengembangan kurikulum dan pembelajaran Matematika. Malang: Penerbit Universitas Negeri Malang.

Johnson, D. W., \& Johnson, R. T. (1994). Learning together and alone: Cooperative, competitive and individualistic learning. Columbus, $\mathrm{OH}$ : Allyn \& Bacon.

Kalyuga, S. (2011). Informing: A cognitive load perspective. Informing Science: The International Journal of an Emerging Transdiscipline, 14(1), 33-45.

Kameda, T., \& Tindale, R. S. (2006). Groups as adaptivedevices: Human docility and group aggregation mechanisms in evolutionary context. In M. Schaller, J. A. Simpson, \& D. T. Kenrick (Eds.) Evolution and social psychology (pp. 317-342). New York, NY: Psychology Press.

Kirschner, F., Pass, F., \& Kirschner, P. A. (2009). Individual and group-based learning from complex cognitive tasks: Effects on retention and transfer efficiency. Computers in Human Behavior, 25(2), 306-314. doi:https://doi.org/10.1016/j.chb.2008.12.008

Laughlin, P. R., Bonner, B. L., \& Miner, A. G. (2002). Groups perform better than the best individuals on letters-to-numbers problems. Organizational Behavior and Human Decision Processes, 88(2), 605-620. doi:http://dx.doi.org/10.1016/S0749-5978(02)00003-1

Laughlin, P. R., Hatch, E. C., Silver, J. S., \& Boh, L. (2006). Groups perform better than the best individuals on letters-to-numbers problems: Effects of group size. Journal of Personality and Social Psychology, 90(4), 644-651. doi:https://doi.org/10.1037/0022-3514.90.4.644

Mevarech, Z. R. (1985). The effects of cooperative mastery learning strategies on mathematics achievement. Journal of Educational Research, 78(6), 372-377. doi:https://doi.org/10.1080/00220671.1985.10885633

Moll, L. C. (1990). Vygotsky and education: Insructional implications and applications of sociohistorical Psychology. New York, NY: Press Syndicate of the University of Cambridge.

Mwangi, W., \& Sweller, J. (1998). Learning to solve compare word problems: The effectof example format and generating self-explanations. Cognition and Instruction, 16(2), 173-199. Retrieved from http://www.jstor.org/stable/3233720

NCTM. (2000). The principles and standards for school mathematics. Reston, VA: Author. 
Paas, F., Touvinen, J. E., Tabbers, H., \& Van Gerven, W. M. (2010). Cognitive load measurement as a means to advance cognitive load theory. Education Psychologist, 38(1), 63-71. doi:https://doi.org/10.1207/S15326985EP3801_8

Primadiati, I. D., \& Djukri, D. (2017). Pengaruh model collaborative learning terhadap peningkatan motivasi dan hasil belajar IPA siswa kelas IV SD. Jurnal Prima Edukasia, 5(1), 47-57. doi:https://doi.org/10.21831/jpe.v5i1.7712

Renkl, A., Atkinson, K. R., Maier, H. U., \& Staley, R. (2002). From example study to problem solving: Smooth transition help learning. The Journal of Experimental Education, 70(4), 293-315. doi:https://doi.org/10.1080/00220970209599510

Retnowati, E. (2008). Keterbatasan memori dan implikasinya dalam mendesain metode pemebelajaran. Paper presented at the Seminar Nasional Matematika dan Pendidikan Matematika. Universitas Negeri Yogyakarta. 31 Juli - 2 Agustus.

Retnowati, E., Ayres, P., \& Sweller, J. (2010). Worked example effects in individual and group work settings. $\quad$ Educational Psychology, 30(3), 349-367. doi:https://doi.org/10.1080/01443411003659960

Retnowati, E. (2012). Worked example in mathematics. Paper presented at the 2nd Internationa STEM in Education Conference, Beijing, China. 24 - 27 November.

Saleh, M., Lazonder, A.W., \& de Jong, T. (2007). Structuring collaboration in mixed-ability groups to promote verbal interaction, learning, and motivation of average-ability students. Contemporary Educational Psychology, 32(3), 314-331. doi:https://doi.org/10.1016/j.cedpsych.2006.05.001

Sato, M. (2012). Mereformasi sekolah (Terjemahan Okamoto Sachie). Tokyo: Pelita/IDCJ.

Soller, A. L. (2001). Supporting social interaction in an intelligent collaborative learning system. International Journal of Artificial Intelligence in Education, 12(1), 40-62. Retrieved from https://telearn.archives-ouvertes.fr/hal-00197321

Stepanek, J. (2000). Problem solving: Getting to the heart of mathematics. A Math and Science Journal, l(1), 1-20.

Sweller, J., \& Cooper, G.A. (1985). The use of worked examples as a substitute for problem solving in learning algebra. Cognition and Instruction, 2(1), 59-89. doi:https://doi.org/10.1207/s1532690xci0201_3

Sweller, J. (2006). The worked example effect and human cognitive. Learning and Instruction, 16(2), 165-169. doi:http://dx.doi.org/10.1016/j.learninstruc.2006.02.005

Sweller, J., Aryes, P., \& Kalyuga, S. (2011). Cognitive load theory, explorations in the learning sciences, instructional system and performance technologies. New York, NY: Springer.

Swing, S. R., \& Peterson, P. L. (1982). The relationship of student ability and small-group interaction to student achievement. American Educational Research Journal, 19(2), 259-274. doi:http://dx.doi.org/10.2307/1162569

Tarmizi, R. A., \& Sweller, J. (1988). Guidence during mathematical problem solving. Journal of Eductional Psychology, 80(4), 424-436. doi:http://dx.doi.org/10.1037/0022-0663.80.4.424

Tindale, R. S., Cristine, M. S., Amanda, D. E., \& Katharina K. (2012). Good and bad group performance: Same process-different outcomes. Group Processes Intergroup Relation,15(5): 603. doi:https://doi.org/10.1177/1368430212454928

Ward, M., \& Sweller, J. (2009). Structuring effective worked examples. Cognitive and Instruction, 7(1), 1-39. doi:https://doi.org/10.1207/s1532690xci0701_1

Webb, N. M. (1991). Task-related verbal interaction and mathematics learning in small groups. Journal for Research in Mathematics Education, 22(5), 366-389. doi:https://doi.org/10.2307/749186

Zajac, R. J., \& Hartup, W. W. (1997). Friends as coworkers: Research review and classroom implications. The Elementary School Journal, 98(1), 3-13. 